\title{
Pruning Practices Affect Yield, Yield Components, and Their Distribution in 'Royalty' Purple Raspberry
}

\author{
Norman A. Gundersheim and Marvin P. Pritts \\ Department of Fruit and Vegetable Science, Cornell University, Ithaca, NY 14853 \\ Additional index words. compensation, primocane suppression, Rubus
}

\begin{abstract}
A factorial arrangement of 48 treatments was used to evaluate the effects of cane density, time of cane density adjustment, primocane tipping, and cane or branch length on yield components in ' $R$ oyalty' purple raspberry [(Rubus occidentals $\times R$. idaeus $) \times R$. idaeus] over 2 years. Yield was positively related to cane density and length, while fruit size and fruit count per lateral were negatively related to cane and branch length. When branches on tipped canes were shortened in late winter, more buds became fruitful at the proximal end of the branch, but fruiting laterals did not have more flowers or fruit. Fruiting laterals were longer on shortened canes, resulting in a decrease in the fruit: wood ratio. Plants performed similarly whether floricane density was adjusted in late winter orprimocane density was adjusted in late spring. Although potential yield was higher when primocanes were tipped in late spring, harvesting was more difficult because of branch orientation, and the incidence of cane blight infection was higher. Our study suggests that maintaining at least 12 canes per meter of row, avoiding primocane tipping, retaining full cane length, and providing adequate light, moisture, and nutrient levels can result in high yields of large fruit.
\end{abstract}

Pruning raspberries can be a complex operation because the optimal pruning system for a particular cultivar depends on inherent vigor, number of primocanes produced, interrelationships among yield components, susceptibility to disease, response to environment, and other genetically determined factors. Red raspberries (Rubus idaeus L.) respond to primocane suppression (Crandall et al., 1980; Lawson and Wiseman, 1983; Nehrbas and Pritts, 1988) and cane density manipulations (Buszard, 1986; Crandall and Carstens, 1962; Crandall et al., 1974a; Johnston and Loree, 1927; Lott, 1931; Teske and Gardener, 1927; Wood, 1960), while black raspberries (R. occidentals L.) respond favorably to the removal of the tops of primocanes during early growth (Cranefield, 1901). However, individual cultivars respond differently to these manipulations (Freeman et al., 1989; Macoun, 1907; Waister et al., 1980), suggesting that specific pruning systems need to be developed for individual cultivars.

Interspecific hybrid raspberry cultivars exhibit excellent vigor, productivity, and disease resistance, but their response to cane manipulation treatments has not been well-studied. Some growers of hybrid raspberries follow pruning and cane thinning recommendations developed for red raspberries, while others follow protocols for black raspberries.

The objective of this study was to identify a pruning system for 'Royalty' purple raspberry that would optimize productivity and fruit quality over the life of the planting. Four aspects of pruning were examined: 1) cane density, 2) time of density adjustment, 3) primocane tipping, and 4) length of canes or branches.

\section{Materials and Methods}

The experiment was located at the Cornell Orchards, Ithaca, N.Y. Tissue-cultered raspberry plants CV. Royalty were set in May 1985 in a Hudson silt loam (Typic Hapludalf) spaced at

Received for publication 9 Apr. 1990. Dept. of Fruit and Vegetable Science paper no. 6. Research was supported in part through Hatch Project 155402. We thank Wayne Sinclair, Barbara Goulart, Marcia Eames-Sheavly, Judy Kozlowski, Monika Cassel, Matt Beaton, Bonnie Dee, Garry Ford, and Lilian Davis for their contributions to this study. The cost of publishing this paper was defrayed in part by the payment of page charges. Under postal regulations, this paper therefore must be hereby marked advertisement solely to indicate this fact.
$2.0 \mathrm{~m}$ in rows with $4.0 \mathrm{~m}$ between rows. The plants were trained to a V-trellis, the floricanes were tied to both sides of the trellis, and the primocanes were allowed to grow up between the floricanes. Fertilizer was applied each year according to need, based on soil and tissue analyses. Insect and disease control was based on need and followed commercial guidelines (Pritts et al., 1987). Soil mositure tension was maintained at $<0.06 \mathrm{MPa}$ using trickle irrigation with emitters spaced every $60 \mathrm{~cm}$. Cultivation was used between the rows to control weeds and prevent sucker development. Hand hoeing and herbicides were used to control weeds within the rows.

Cultivar. 'Royalty' is an interspecific hybrid purple raspberry derived from a backcross between purple raspberry N.Y. 253 and red raspberry N.Y. 17861 (Sanford and Ourecky, 1982). 'Royalty' has large, flavorful fruits and plants are vigorous, productive, winter hardy, and immune to the aphid vector of raspberry mosaic virus. The growth habit of canes is more like the red raspberry, which comprises $75 \%$ of its parentage. Most new primocanes, however, are produced from the crown rather than from adventitious buds on the roots.

Design of experiments. The factorial experiment consisted of 48 treatments with three replications of single plant units in a completely randomized design. Factors and levels were: 1) cane density, four levels; 2) time of cane density adjustment, two levels; 3) primocane tipping, two levels; and 4) cane or branch length adjustment of floricanes, three levels. The four levels of cane density were 4, 6, 8, and 12 per plant (hill). Density adjustments were made either in late spring when primocanes were $\approx 30 \mathrm{~cm}$ long, or in late winter when floricanes were dormant. Primocane tipping occurred in summer when canes were $\approx 1.0 \mathrm{~m}$ in length. The top $10 \mathrm{~cm}$ was removed from primocanes in tipped treatments to stimulate lateral branching; untipped primocanes remained unaltered. Branch lengths for tipped treatments were adjusted in late winter to $15 \mathrm{~cm}, 30 \mathrm{~cm}$, or they remained unadjusted ( $>30$ to $<150 \mathrm{~cm}$ ); cane lengths for untipped treatments were $60 \mathrm{~cm}, 120 \mathrm{~cm}$, or unadjusted (> 120 to $<250 \mathrm{~cm}$ ). The treatments were applied in 2 consecutive years, beginning in 1986 .

Components of yield. In early summer, just before harvest, the number of dead, vegetative, and fruitful laterals in $15-\mathrm{cm}$ increments along the branches and $30-\mathrm{cm}$ increments along the 
main canes were counted for three representative canes per treatment. The number of flowers per lateral, fruits per lateral, and lateral length for three randomly selected fruiting laterals per increment were also measured. Fruit weight (fresh weight) was estimated from a 50-fruit subsample per treated plant, five or more times throughout the season (Daubeny et al., 1986). Finally, after harvest, the fresh weight of all expended fruiting canes from the individual plants was recorded.

Estirnate of yield. Yield was estimated for each plant by multiplying the following average values for yield components: cane density $\times$ total buds per cane $\times$ percent fruitful buds $x$ fruit per fruiting lateral $\times$ mean fruit weight. The accuracy of the yield estimation procedure used was verified by comparing actual yields with estimated potential yields for canes from 24 treatments.

Statistical analyses. Analysis of variance (ANOVA) techniques appropriate for the experimental design were used to test for the significance of factors and differences among levels within factors. Because of the large amount of variability between years due to winter injury in 1988, and because levels of floricane shortening are not directly comparable to levels of branch shortening, separate ANOVAs were performed for year-tipping combinations (Table 1). In a separate analysis, the results of the unshortened, untipped treatment were compared with those of the unshortened, tipped treatment to quantify the effect of primocane tipping alone.

Regression analysis was used to quantify the response of measured variables to cane density. Path analysis (Wright, 1921),

Table 1. Yield component ANOVA for density (DEN), cane or branch length (LEN), and time of thinning (TOT) for tipped and untipped plants in 1987 and 1988. Numbers are F-statistic probabilities for various sources of variation.

\begin{tabular}{|c|c|c|c|c|c|c|}
\hline \multirow[b]{2}{*}{ Year } & \multirow[b]{2}{*}{ Tipping } & \multirow[b]{2}{*}{ Source } & \multirow[b]{2}{*}{$\mathrm{df}$} & \multicolumn{3}{|c|}{ Yield components ${ }^{\mathbf{z}}$} \\
\hline & & & & $\begin{array}{l}\text { Estimated } \\
\text { yield }\end{array}$ & $\begin{array}{l}\mathrm{Wt} / \\
\text { fruit }\end{array}$ & $\begin{array}{l}\text { Fruit/ } \\
\text { lateral }\end{array}$ \\
\hline \multirow[t]{7}{*}{$19 \overline{8} 7$} & \multirow[t]{7}{*}{+} & DEN & 3 & 0.001 & NS & NS \\
\hline & & LEN & 2 & 0.001 & 0.06 & 0.02 \\
\hline & & TOT & 1 & NS & NS & NS \\
\hline & & DEN ${ }^{*}$ LEN & 6 & NS & NS & NS \\
\hline & & $\mathrm{TOT}^{*} \mathrm{DEN}$ & 3 & NS & NS & NS \\
\hline & & TOT*LEN & 2 & 0.01 & NS & NS \\
\hline & & DEN*TOT*IEN & 6 & NS & NS & NS \\
\hline \multirow[t]{7}{*}{1987} & \multirow[t]{3}{*}{ - } & DEN & 3 & 0.001 & NS & NS \\
\hline & & LEN & 2 & 0.001 & 0.0001 & 0.01 \\
\hline & & TOT & 1 & 0.05 & 0.03 & NS \\
\hline & \multirow[t]{4}{*}{-. } & DEN*LEN & 6 & 0.01 & NS & NS \\
\hline & & TOT*DEN & 3 & NS & NS & NS \\
\hline & & $\mathrm{TOT}^{*} \mathrm{LEN}$ & 2 & NS & NS & NS \\
\hline & & DEN $^{*}$ TOT*LEN & 6 & 0.02 & NS & NS \\
\hline \multirow[t]{7}{*}{1988} & \multirow[t]{7}{*}{+} & DEN & 3 & 0.02 & 0.02 & NS \\
\hline & & LEN & 2 & 0.01 & 0.07 & 0.01 \\
\hline & & TOT & 1 & NS & 0.01 & NS \\
\hline & & DEN*LEN & 6 & NS & NS & 0.05 \\
\hline & & TOT*DEN & 3 & NS & 0.01 & NS \\
\hline & & TOT*LEN & 2 & NS & NS & NS \\
\hline & & DEN*TOT*LEN & 6 & NS & NS & NS \\
\hline \multirow[t]{7}{*}{1988} & \multirow[t]{7}{*}{ - } & DEN & 3 & 0.001 & NS & NS \\
\hline & & LEN & 2 & 0.001 & 0.03 & 0.001 \\
\hline & & TOT & 1 & NS & NS & 0.05 \\
\hline & & DEN*LEN & 6 & 0.03 & NS & NS \\
\hline & & TOT*DEN & 3 & NS & NS & NS \\
\hline & & TOT*LEN & 2 & NS & NS & NS \\
\hline & & DEN*TOT*LEN & 6 & NS & NS & NS \\
\hline
\end{tabular}

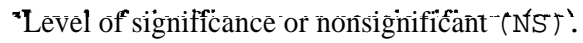

a modification of regression analysis, was used to quantify relationships among yield components and to rank the relative importance of the components in determining yield. Path coefficient analysis partitions correlation coefficients into their direct and indirect effects. A direct effect is the estimated relative influence of one yield component on another when remaining components are held constant. Specific factors acting to produce a given correlation can then be examined to determine their relative importance.

\section{Results}

Yield estimation. Actual yields were closely predicted by the yield estimation procedure [Actual yield $(\mathrm{g})=0.74$ (Estimated yield) $\left.+122, R^{2}=0.76, P<0.01\right]$. In subsequent analyses, estimated yields were used.

Time of thinning. The time of cane thinning had little effect on plant productivity (Table 1). In 1987, winter-thinned plants had higher yields than summer-thinned plants, and an interaction occurred with cane density. However, yields were similar for both winter- and summer-thinned groups at either the lowest or highest cane densities; only six- and eight-cane plants with winter thinning had higher yields. Therefore, it is unlikely that this interaction has biological meaning. Because the time of thinning had no real effect on plant productivity, the tables of means contain values averaged over the time of thinning factor (Tables 2,3, and 4).

Cane density. Yield increased significantly with cane density across all levels of cane or branch length (Table 2). A path analysis of yield components using two contrasting treatment groups (untipped, winter-thinned plants in 1987 and tipped, summer-thinned plants in 1988) also reflected the positive association between cane density and yield (Figs. 1 and 2). Individual fruit weight remained relatively constant with changing cane density (Table 3). A significant negative association between weight per fruit and density occurred only in the 1988, tipped, 60-cm branch length treatments ( $\mathrm{B}=-0.13, r=0.50$, $P<0.02)$. Fruit count per lateral was also unaffected by density (Table 4); no significant correlations with density were found, and path coefficients were nonsignificant (Figs. 1 and 2).

Cane length. Cane and branch length affected yield (Table 1), with yields increasing as length increased (Table 2). Path analysis (Figs. 1 and 2) indicated that bud count per cane had the greatest single influence on yield among the various yield components. Although longer canes and branches had higher bud counts, fruit counts per lateral were lower, reflecting the inherent trend of more distal buds producing fewer flowers. However, when only the first $15-\mathrm{cm}$ increments of branches were compared for shortened and unshortened canes, the mean count of flowers or fruits per lateral was not different, but more buds along the increment were fruitful when branches were shortened (Table 5). When floricanes, rather than branches, were shortened, the proportion of buds that fruited did not change, although lateral length was much greater on shortened canes (data not presented).

The weight of individual fruits increased significantly with floricane shortening (Tables 1 and 3), but the response to branch shortening was not as strong. Path analysis also detected a negative relationship between individual fruit weight and bud count per floricane (a reflection of cane length).

Cane density and length of floricanes or branches were positively related to the weight of expended floricanes. The ratio of fruit to expended floricane weight, a measure of reproductive efficiency, increased significantly with length for both tipped 
Table 2. Effects of cane density and branch or cane length on total plant yield in 1987 and 1988. Values are the mean of six experimental units averaged over time of thinning. All regression coefficients of total yield per plant against density are significant at $<0.05$.

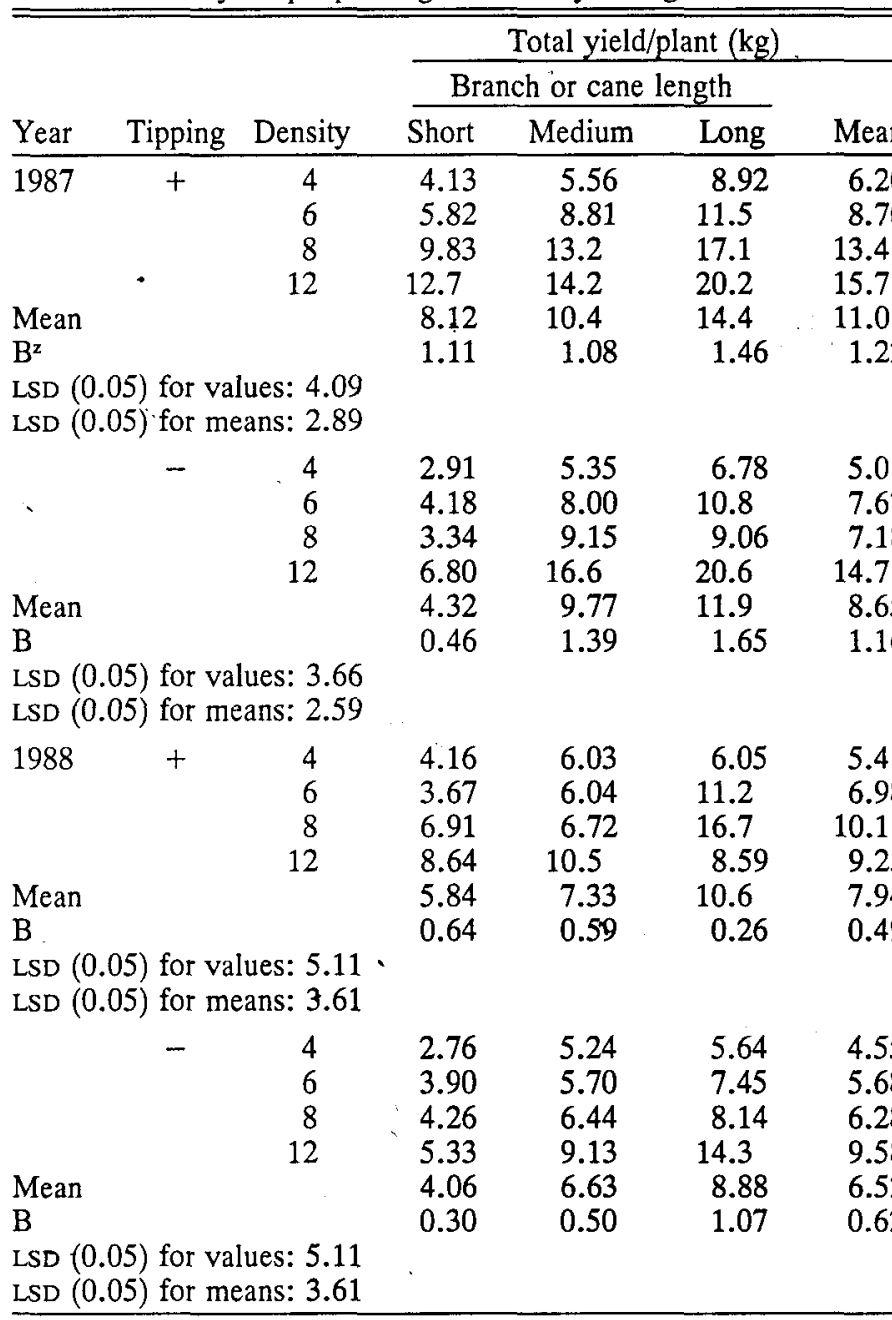

'Linear regression coefficient (B) of total yield per plant against density (kg/cane).

and untipped plants in 1987, and for tipped plants in 1988. In untipped plants, the yield response to density also increased as cane length increased; this accounts for the significant interaction between density and length. Both of these observations indicate that upper portions of floricanes are more productive than lower protions. The same trend was not evident with branch length; with 1988 tipped plants, the yield response to cane density decreased with increasing branch length.

Primocane tipping 'Royalty' puces branches on primocanes when the growing point is removed in midsummer, resulting in floricanes with many buds. In both years, floricanes with branches produced $\approx 27 \%$ more total yield than plants without branches at a given density $(P<0.05)$, but individual fruit size was not significantly different. Path analysis indicated that floricanes with more buds tend to produce smaller fruit (Figs. 1 and 2), but this trend was evident only within plants of the same growth habit. In 1988 , yields were $\approx 20 \%$ less than in 1987 because of winter injury to canes. In addition, many tipped primocanes became infected with the caneblight fungus, Leptospheria coniothyrium (Fuckel) Sacc., which reduced yields. Individual fruit weight was greater in 1988 because there were fewer fruit.
Table 3. Effects of cane density and branch or cane length on individual fruit weight in 1987 and 1988 . Values are the mean of six experimental units averaged over time of thinning. Linear regressions of weight per fruit on cane density are not significant for any year-tipping-length combination, except where noted.

\begin{tabular}{lcccccc}
\hline & & \multicolumn{4}{c}{ Wt/fruit (g) } \\
\cline { 3 - 6 } & & \multicolumn{3}{c}{ Branch or cane length } \\
\cline { 3 - 5 } Year & Tipping & Density & Short & Medium & Long & Mean \\
\hline 1987 & + & 4 & 3.88 & 3.96 & 3.65 & 3.83 \\
& & 6 & 3.92 & 3.66 & 3.38 & 3.65 \\
& & 8 & 4.01 & 3.89 & 3.65 & 3.85 \\
& 12 & 3.63 & 3.66 & 3.41 & 3.56 \\
Mean & & 3.87 & 3.79 & 3.52 & 3.73
\end{tabular}

LSD (0.05) for values: 0.59

LSD $(0.05)$ for means: 0.42

\begin{tabular}{lrrrrr} 
& 4 & 4.45 & 3.54 & 3.19 & 3.73 \\
& 6 & 4.16 & 3.73 & 3.67 & 3.85 \\
& 8 & 3.72 & 3.50 & 3.32 & 3.51 \\
& 12 & 4.34 & 4.15 & 3.37 & 3.95 \\
Mean & & 4.17 & 3.73 & 3.38 & 3.76 \\
LSD (0.05) for values: 0.65 & & & & \\
\multicolumn{2}{l}{ LSD (0.05) for means: 0.46} & & & & \\
$1988 \quad+\quad$ & 4 & 4.47 & $5.20^{z}$ & 4.20 & 4.62 \\
& 6 & 4.22 & 4.71 & 4.24 & 4.39 \\
& 8 & 4.91 & 4.51 & 4.56 & 4.66 \\
& 12 & 4.36 & 4.03 & 3.75 & 4.04 \\
Mean & & 4.49 & 4.61 & 4.19 & 4.43
\end{tabular}

LSD (0.05) for values: 0.87

LSD (0.05) for means: 0.62

$\begin{array}{rcccc}-4 & 5.33 & 4.22 & 4.18 & 4.57 \\ 6 & 4.62 & 4.77 & 4.30 & 4.56 \\ 8 & 4.61 & 4.21 & 4.58 & 4.47 \\ 12 & 4.62 & 4.70 & 4.00 & 4.44 \\ & 4.79 & 4.47 & 4.26 & 4.51\end{array}$

Mean
LSD $(0.05)$ for values: 0.87

LSD $(0.05)$ for means: 0.62

${ }^{2}$ Only this column is significantly associated with cane density $(\mathrm{B}=$ $-0.13, r=0.50, P<0.02)$.

\section{Discussion}

Cane density. Our study found floricane density to be an important contributor to yield. Yield increased significantly with floricane density, and cane density had a strong direct effect on yield as determined by path analysis (Figs. 1 and 2). When winter injury was minimal (1987), the yield response to cane density was greater than when injury was severe (1988).

The contribution of cane density to yield has been quantified by other researchers (Buszard, 1986; Crandall and Carstens, 1962; Crandall et al., 1974a; Johnston and Loree, 1927; Lott, 1931; Odyvin, 1986; Orkney and Martin, 1980; Teske and Gardener, 1927; Wood, 1960). In general, increasing cane density per unit area increases yield, even though there may be some reduction in yield per cane with increasing density. Nehrbas and Pritts (1988) also found that cane density had the strongest direct effect on yield of any yield component in the summer-bearing cultivar Royalty.

We did not determine if increasing cane density above 12 per plant would also increase yield, but at some point, the yield contribution from additional canes should become minimal. Several authors have indicated that yield reaches a plateau as cane density increases, and that there may be an optimum density for high yields of good quality fruit (Buszard, 1986; Johnston and Loree, 1927; Wood, 1976). For 'Royalty', and possibly 
Table 4. Effects of cane density and branch or cane length on fruit per lateral in 1987 and 1988. Values are the mean of six experimental units averaged over time of thinning. Linear regressions of fruit per lateral on cane density are not significant for any year-tipping-length combination.

\begin{tabular}{|c|c|c|c|c|c|c|}
\hline \multirow[b]{3}{*}{ Year } & \multirow[b]{3}{*}{ Tipping } & \multirow[b]{3}{*}{ Density } & \multicolumn{4}{|c|}{ - Fruit/lateral } \\
\hline & & & \multicolumn{3}{|c|}{ Branch or cane length } & \multirow{2}{*}{ Mear } \\
\hline & & & Short & Medium & Long & \\
\hline 1987 & + & $\begin{array}{r}4 \\
6 \\
8 \\
12\end{array}$ & $\begin{array}{l}10.6 \\
12.6 \\
12.8 \\
11.6\end{array}$ & $\begin{array}{l}10.2 \\
11.9 \\
11.0 \\
10.2\end{array}$ & $\begin{array}{l}8.3 \\
7.8 \\
7.6 \\
8.2\end{array}$ & $\begin{array}{r}9.7 \\
10.8 \\
10.5 \\
10.0\end{array}$ \\
\hline \multicolumn{7}{|c|}{$\begin{array}{l}\text { Mean } \\
\text { LSD }(0.05) \text { for values: } 3.0 \\
\text { LSD }(0.05) \text { for means: } 2.1\end{array}$} \\
\hline - & - & $\begin{array}{r}4 \\
6 \\
8 \\
12\end{array}$ & $\begin{array}{l}15.5 \\
17.8 \\
14.5 \\
15.2\end{array}$ & $\begin{array}{l}14.1 \\
13.4 \\
14.1 \\
13.9\end{array}$ & $\begin{array}{l}13.3 \\
12.5 \\
11.7 \\
12.8\end{array}$ & $\begin{array}{l}14.3 \\
14.5 \\
13.4 \\
14.0\end{array}$ \\
\hline \multicolumn{7}{|c|}{$\begin{array}{l}\text { LSD }(0.05) \text { for values: } 2.4 \\
\text { LSD }(0.05) \text { for means: } 1.7\end{array}$} \\
\hline 1988 & + & $\begin{array}{r}4 \\
6 \\
8 \\
12\end{array}$ & $\begin{array}{r}9.2 \\
8.6 \\
10.9 \\
10.5 \\
0.8\end{array}$ & $\begin{array}{l}9.5 \\
9.2 \\
8.3 \\
8.8\end{array}$ & $\begin{array}{l}7.8 \\
8.4 \\
8.2 \\
6.4 \\
7\end{array}$ & $\begin{array}{l}8.8 \\
8.7 \\
9.1 \\
8.6\end{array}$ \\
\hline \multicolumn{7}{|c|}{$\begin{array}{l}\text { LSD }(0.05) \text { for values: } 2.0 \\
\text { LSD }(0.05) \text { for means: } 1.4\end{array}$} \\
\hline & - & $\begin{array}{r}4 \\
6 \\
8 \\
12\end{array}$ & $\begin{array}{r}18.3 \\
17.7 \\
12.9 \\
19.6\end{array}$ & $\begin{array}{l}15.5 \\
13.0 \\
11.6 \\
12.3\end{array}$ & $\begin{array}{r}12.2 \\
10.5 \\
11.1 \\
9.2\end{array}$ & $\begin{array}{l}15.4 \\
13.8 \\
11.9 \\
13.7\end{array}$ \\
\hline $\begin{array}{l}\text { Mean } \\
\text { LSD (0 } \\
\text { LSD (0 }\end{array}$ & $\begin{array}{l}\text { for va } \\
\text { for } m\end{array}$ & $\begin{array}{l}\text { ues: } 2.0 \\
\text { ans: } 1.4\end{array}$ & 17.1 & 13.1 & 10.7 & 13.6 \\
\hline
\end{tabular}

for other vigorous, large-fruited cultivars, the optimum density may be different than for less vigorous, smaller fruited cultivars. Further study is needed to determine the optimal cane density in relation to management and site characteristics.

Cane length. Cane length can also be adjusted during pruning to influence yield. The need for manipulation of length depends on the amount of natural branching. Red raspberries, with few exceptions, tend not to branch naturally, and grow as single canes. For this reason, all adjustments to length are usually done to the floricane during the dormant season. Black and some purple raspberries tend to branch naturally, and can be encouraged to branch by tipping the primocane during the growing season. Branch length is then adjusted in the late winter or early spring when the canes are still dormant (Pritts and Handley, 1989).

In our study with 'Royalty', we observed notable increases in fruiting lateral count per unit length of cane and fruit count per lateral with branch shortening, but we did not observe a large response in individual fruit weight. Johnston (1925), working with 'Cumberland' black raspberry, found that the shorter the branches, the greater the percentage of the total buds that produced fruitful laterals along the main cane and branches. Crandall et al. (1974b) also found that increasing pruning severity increased berry count per lateral with 'Puyallup'. Shoemaker et al. (1930), Lott (1931), Locklin (1931), Brierley (1931, 1934), Wood et al. (1961), Martin et al. (1980), and Odyvin (1986) have all documented a positive effect of cane or branch length on fruit count, but, unlike us, most found a strong, negative effect on fruit size.

The smaller negative response of individual fruit weight to cane and branch length that we observed may be due to the environmental conditions under which the plants were grown. Our plots were drip-irrigated, trellised, nutrient levels were adjusted with leaf analysis, and plants were widely spaced. Compensatory relationships among yield components are likely to be less when resource levels (water, nutrients, light, etc.) are high. For example, in a multi-year study by Johnston and Loree (1927) using 'Cuthbert', yield was decreased with moderate to severe shortening of the main cane, while fruit size was affected only during the driest year. Brierley $(1931,1934)$ also observed varying responses to pruning and concluded that raspberry cane performance is more dependent on moisture supply than on pruning treatment. In a separate study conducted with 'Royalty' on an unirrigated site (Nehrbas and Pritts, 1988), compensatory relationships among yield components were much stronger than those we observed.

We found that, in a year when winter injury was minimal, plants with unshortened laterals or canes appeared to be more efficient at producing fruit. Plants with long canes or branches

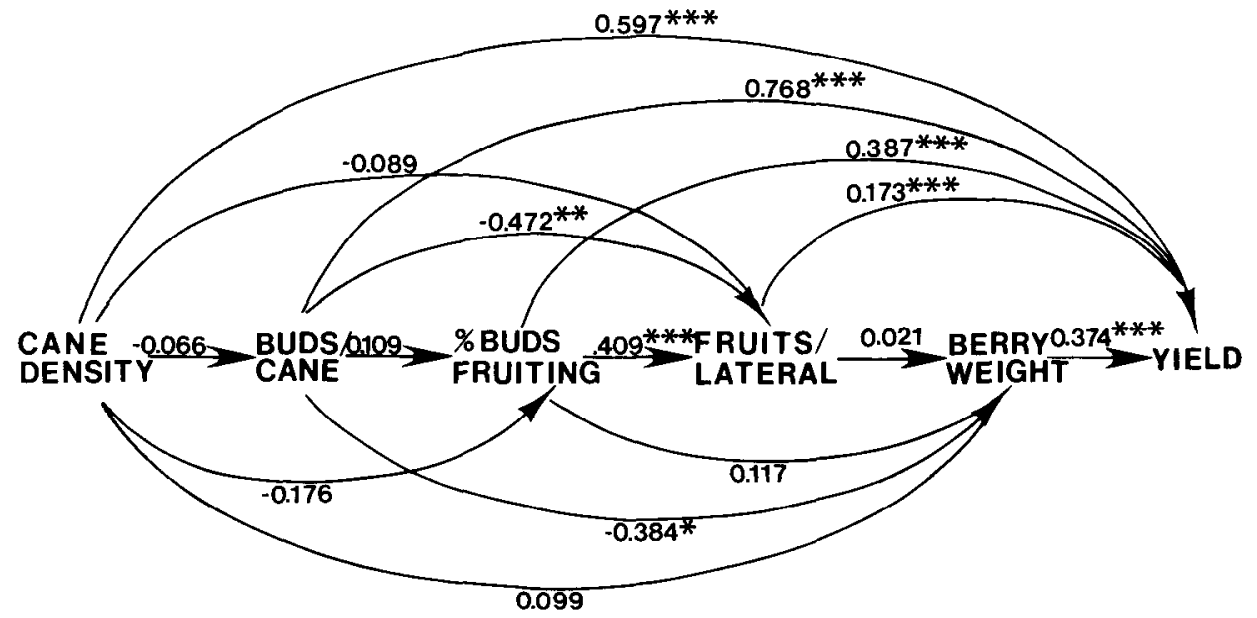

Fig. 1. Path analysis diagram of interrelationships among yield components for untipped winter-thinned plants, 1987. Numbers represent relative measures of direct effects. Levels of significance: ${ }^{*} P=0.1,{ }^{* *} P=0.01,{ }^{* * *} P=0.001$. 


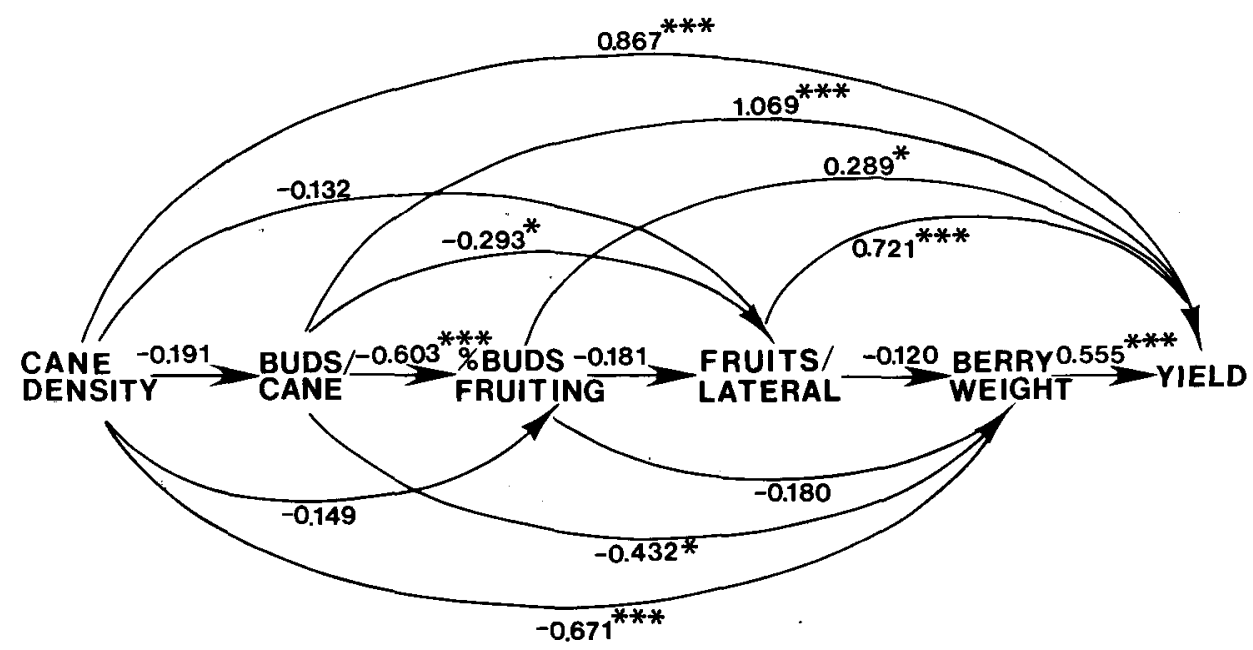

Fig. 2. Path analysis diagram of interrelationships among yield compnents for tipped summer-thinned plants. 1988. Numbers represent relative measures of direct effects. Levels of significance: $* P=0.1, * * P=0.01, * * * P=0.001$.

Table 5. Effect of branch length adjustment on number of fruiting laterals in the proximal $15-\mathrm{cm}$ segment of branches for tipped canes in 1987.

\begin{tabular}{lc}
\hline Cane length & Fruiting laterals (no.) \\
\hline Short $(15 \mathrm{~cm})$ & 3.56 \\
Medium $(30 \mathrm{~cm})$ & 1.47 \\
Long (unpruned) & 1.25 \\
LSD & 1.76 \\
\hline
\end{tabular}

produced a higher ratio of fruit to wood than plants with shortened canes or branches, despite the observation that a greater precentage of buds were fruitful in proximal regions of shortened canes or branches. Shortened canes and branches produced longer laterals than unpruned plants, although flower count per lateral on the same cane increment remained unchanged. The greater amount of woody tissue contained in the longer laterals of shortened canes appears to be the reason why the fruit: wood ratio decreases. These data; together with observations on the effect of cane shortening, suggest that the distal ends of floricanes are more productive per unit length than proximal ends.

Time of cane density adjustment. Early reports on raspberry culture indicated that cane thinning was normally done to floricanes during the dormant season. Card (1917), however, recommended that during the last year in the life of a planting, all primocanes should be removed in late spring so plants will be more productive. The idea of annually thinning primocanes in late spring was first presented by Lott (1931). Although many workers have examined the response of raspberries to complete primocane suppression or removal (Crandall et al., 1980; Lawson and Wiseman, 1983; Nehrbas and Pritts, 1988; Waister et al., 1977), partial primocane removal, as suggested by Lott (1931), has not been explored for most cultivars (Swartz, 1986).

Our data suggest that no consistent benefit was obtained from altering the standard time of cane thining. Primocane thinning in late spring is labor intensive and tedious, it occurs when labor is required for other farm operations but is physically less demanding than winter thinning. Cane thinning in late winter is difficult because of larger cane size and the usually unfavorable weather, but labor is usually more available then. Although our study found no benefit of early primocane thinning, a pilot study in an unirrigated planting in Ithaca indicated that late spring thinning of primocanes would be beneficial. Again, evidence suggests that environmental conditions have a marked effect on the pruning response.

Primocane tipping. In our study, tipping resulted in more buds per cane and, subsequently, more fruit. However, fruit was much more difficult to harvest with tipping treatments because many of the branches were positioned in the center of the canopy. In addition, severe cane dieback occurred in 1988 on tipped floricanes due to the caneblight fungus Leptospheria coniothyrium. Although an overall yield increase could occur as the result of tipping canes, this practice is not attractive in 'Royalty' because of difficulty in harvesting and potential for disease infection.

In untipped plants, we observed that, as cane length increased, the yield response to density also increased. The same trend was not evident with branch length; in fact, with plants tipped in 1988, the yield response to cane density decreased with increasing branch length. This result suggests that intercane competition was greater when primocanes were tipped; longer branches seemed to reduce the contribution of cane density to plant productivity.

Fuller (1867), Roe (1886), and Taft and Lyon (1899) recommended that raspberry primocanes be tipped, but they provided no experimental support for their recommendations. Goff (1900) and Cranefield (1901) compared several tipping treatments with 'Cuthbert', a red raspberry, and 'Gregg', a black raspberry. Tipping had a positive effect on yield of the black raspberry, but a negative effect on the red raspberry. In Canada, Macoun (1907) found that tipping suppressed the yield of 17 red raspberry cultivars. Our results with the hybrid 'Royalty' show that tipping can increase potential yield, but realizing this yield can be problematic.

Conclusions. In our study, cane density was an important component influencing yield. Individual fruit weight and fruit count per lateral did not decrease with increasing cane density, although path analysis indicated the tendency of higher cane densities to be associated with smaller fruit when other yield components did not vary. Maintaining at least 12 canes per plant did not result in smaller berries when water and nutrients were maintained at high levels.

The time of cane density adjustment did not consistently affect productivity under our condtions, although early thinning might reduce intraplant competition and result in higher yields under less optimal conditions. 
Tipping primocanes to promote branching resulted in more fruitful laterals and larger yields than not tipping, but harvesting the heavily branched canes was difficult and tipping predisposed the plants to disease infection. Tipping negatively affected the ability of cane density to contribute to higher yields.

Shortening canes resulted in a decrease in yield, but an increase in weight per fruit. Shortening branches resulted in more fruitful laterals at the proximal end of the branch, but weight per fruit did not change significantly. The average fruit count per lateral on shortened branches was greater because distal fruiting buds have fewer flowers, but fruit counts per lateral on the proxima! ends of branches were not affected by shortening. With 'Royalty', good production can be realized by maintaining adequate levels of resources, thinning canes to a minimum of 12 per meter of row, avoiding tipping of primocanes, waiting until winter injury is assessed before shortening the canes, and then removing only the winter-injured portion. If large berries are desired for a specialty market, reducing cane or branch length will increase berry size, but at the expense of yield.

\section{Literature Cited}

Brierley, W.G. 1931. The effects of height of pruning on size of berries and yield in the 'Latham' raspberry. Minn. Agr. Expt. Sta. Brrl. 281.

Brierley, W.G. 1934. Response of 'Latham' raspberry to pruning. Minn. Agr. Expt. Sta. Tech. Bul. 100.

Buszard, D.J.I. 1986. The effect of management system on winter survival and yield of raspberries in Quebec. Acts Hort. 183:175181.

Card, F.W. 1917. Bush-fruits. Pruning black raspberries. Macmillan, New York. p. 73.

Crandall, P.C. and M.W. Carstens. 1962. Raspberry plant population and management. Proc. Western Wash. Hort. Assn. 52:98-100.

Crandall, P. C., J.D. Allmendinger, J.D. Chamberlain, and K.A. Biderbost. 1947a. Influence of cane number and diameter, irrigation, and carbohydrate reserves on the fruit number of red raspberries. J. her. Soc. Hort. Sci. 99:524-526.

Crandall, P. C., J.D. Chamberlain, and K.A. Biderbost. 1974b. Cane characteristics associated with berry number of red raspberry. J. Amer. Soc. Hort. Sci. 99:370-372.

Crandall, P. C., J.D. Chamberlain, and J.K.L. Garth. 1980. The effects of chemical primocane suppression on growth, yield and chemical composition of red raspberries. J. Amer. Soc. Hort. Sci. 105:194196.

Cranefield, F. 1901. Third report on experiment in pinching raspberry shoots. Univ. Wise. Agr. Expt. Sta. 18th Annu. Rpt. p. 317-320.

Daubeny, H. A,, A Dale, and G. McGregor. 1986. Estimating yields of red raspberries in small research plots. HortScience 21:12161217.

Freeman, J. A., G.W. Eaton, T.E. Baumann, H.A. Daubeny, and A, Dale. 1989. Primocane removal enhances yield components of raspberries. J. Amer. Soc. Hort. Sci. 114:6-9.

Fuller, A.S. 1867. The small fruit culturist. Pruning raspberries. Orange Judd, New York. p. 134-135.

Goff, E.S. 1900. Second report on experiment in pinching raspberry shoots. Wise. Agr. Expt. Sta. 17th Annu. Rpt. p. 286-290.
Johnston, S. 1925. Winter pruning the black raspberry. Mich. Agr. Expt. Sta. Spec. Bul. 143.

Johnston, S. and R.E. Loree. 1927. Pruning the red raspberry. Mich. Agr. Expt. Sta. Spec. .Bul. 162.

Lawson, H.M. and J.S. Wiseman. 1983. Techniques for the control of cane vigor in red raspberry in Scotland: Effects of timing and frequency of cane removal treatments on growth and yield in CV. Glen Clova. J. Hort. Sci. 58:247-260.

Locklin, H.D. 1931. Effects of different methods of pruning raspberries on earliness, weight of fruit and yield. Proc. Wash. State Hort. Assn. 22nd Annu. Mtg. p. 185-189.

Lott, R.V. 1931. A preliminary study of the fruiting habit of the red raspberry Rubus strigosus. Colo. Expt. Sta. Bul. 367.

Macoun, W.T. 1907. Bush fruits. Can. Dept. Agr. Central Expt. Farm Bul. 56:38-39.

Martin, L. W., E. Nelson, and M.H. Chaplin. 1980. Plant and fruit measurements of 'Meeker' red raspberry related to pruning height and nitrogen application. Acts Hort. 112:157-161.

Nehrbas, S.R. and M.P. Pritts. 1988. Effect of pruning system on yield components of two summer-bearing raspberry cultivars. J. Amer. Soc. Hort. Sci. 113:314-321.

Odyvin, J. 1986. The Gjerde method for training raspberries: Effects of increasing cane number and cane height. Acts Hort. 183:173175 .

Orkney, G.D. and L. W. Martin. 1980. Fruiting potential and flower truss characteristics of select 'Willamette' red raspberry canes. Acts Hort. 112:195-203.

Pritts, M.P. and D. Handley. 1989. Bramble production guide. Northeast Regional Agr. Eng. Soc. Pub.

Pritts, M. P., W.F. Wilcox, A. Agnello, and G. Schaefers. 1987. Cornell recommendations for small fruit production. New York State College Agr. Life Sci., Cornell Univ., Ithaca.

Roe, E.P. 1886. Success with small fruits. Raspberry-pruning-stakingmulching-winter protection. Dodd, Mead, New York, p. 167-168.

Sanford, J.C. and D.K. Ourecky. 1982. 'Royalty' a purple raspberry. HortScience 18:109-110.

Shoemaker, J. S., C.W. Bennett, and J.S. Heuser. 1930. Raspberries and blackberries in Ohio. Ohio Agr. Expt. Sta. Bu1. 454. p. 17-27.

Swartz, H.J. 1986. A summary of a decade of change in the raspberry industry. New York State Hort. Soc. Proc. $131: 80-81$.

Taft, L.R, and T.T. Lyon. 1899. Notes from the South Haven substation. Mich. Agr. College Expt. Sta. Bul. 169. p. 154.

Teske, A.H. and V.R. Gardner. 1927. Management methods in the raspberry plantation. Mich. Agr. Expt. Sta. Spec. Bul. 165. p. 1618.

Waister, P. D., M.R. Cormack, and W.A. Sheets. 1977. Competition between fruiting and vegetative phases in the red raspberry. J. Hort. Sci. 52:72-85.

Waister, P. D., C.J. Wright, and M.R. Cormack. 1980. Potential yield in red raspberry as influenced by interaction between genotype and cultural methods. Acts Hort. 112:273-282.

Wood, C.A. 1960. Commercial raspberry growing: The integration of cultural factors. Scientia Hort. 14:97-103.

Wood, C.A. 1976. Commercial raspberry growing-a critique. Scientia Hort. 27:127-131.

Wood, C. A., M.M. Anderson, and G.H. Freeman. 1961. Studies on the cultivation of raspberries: Effects of planting distances and of the winter tipping of canes. Hort. Res. 1:3-24.

Wright, S. 1921. Correlation and causation. J. Agr. Res. 20:557-585.

Wright, C,J. and P.D. Waister. 1982. Within-plant competition in the red raspberry. II. Fruiting cane growth. J. Hort. Sci. 57:443-448. 